\title{
PENINGKATAN BAGIAN HARGA YANG DITERIMA PETANI KARET MELALUI PEMASARAN TERORGANISIR
}

\author{
Increasing Rubber Farmer's Share Prices Through Organized Marketing \\ Iman Satra Nugraha, Aprizal Alamsyah, dan Dwi Shinta Agustina \\ Balai Penelitian Sembawa, Pusat Penelitian Karet, \\ Jalan Raya Palembang - P. Balai KM 29, PO BOX 1127 Palembang 30001 \\ Email : iman_satra@yahoo.com
}

Diterima 29 Januari 2019/ Direvisi 30 Maret 2019 / Disetujui 4 April 2019

\begin{abstract}
Abstrak
Pemasaran bokar yang efesien salah satunya adalah melalui pemasaran bokar secara terorganisir dengan sistem lelang maupun kemitraan. Pemasaran sistem lelang dan kemitraan menyebabkan bagian harga yang diterima petani lebih tinggi daripada pemasaran tradisional, sehingga pemasaran terorganisir lebih efisien dibandingkan dengan pemasaran tradisional. Oleh karena itu penelitian ini dilakukan bertujuan untuk melihat bagian harga yang diterima oleh petani dengan menggunakan pemasaran bokar terorganisir dan tradisional. Pengambilan sampel dilakukan secara purposive, sedangkan data yang digunakan adalah data primer dan sekunder. Pengolahan data dilakukan secara kuantitatif dan kualitatif. Berdasarkan hasil penelitian menunjukkan bahwa dengan menggunakanpetani yang melalui pemasaran bokar terorganisir akan mendapatkan bagian harga yang lebih tinggi dibandingkan pemasaran bokar secara tradisional. Rata-rata bagian harga yang diterima adalah $80 \%$ FOB untuk pemasaran bokar terorganisir dan $50 \%$ $58 \%$ FOB untuk pemasaran bokar tradisional. Selain itu juga ada beberapa manfaat dengan menggunakan pemasaran bokar terorganisir, yaitu seperti mutu bokar lebih baik, posisi tawar petani meningkat, harga lelang menjadi patokan bagi pedagang perantara, dan petani yang sudah berkelompok akan memudahkan pemerintah dalam melakukan pembinaan mutu bokar maupun penyaluran bantuan
\end{abstract}

petanikaret.

Kata kunci : pemasaran bokar, bagian harga petani, pemasaran terorganisir, pemasaran tradisional

\section{Abstract}

Efficient raw rubber material marketing is one of them through raw rubber material marketing in an organized by auction and partnership systems. The marketing of auction and partnership systems causes the farmers share be higher than traditional marketing, so organized marketing is more efficient. This research was conducted to see the farmers share using traditional and organized marketing. Sampling is done pupposively, while the data used are primary and secondary with quantitavely and quantitatively and qualitatively. Based on the results, this study showing the farmers share by organized marketing will get a higher rubber prices than not organized. The average portion of farmers share is $80 \%$ FOB by organized marketing and $50 \%$ 58\% FOB fot tradisional marketing. In addition, there are also some benefitd of using organized marketing, which is like better raw material suppliers, farmers bargaining position increases, auction prices become a benchmark for trades, and group farmers who will help the government improve raw material welfare as well as rubber farmer aid distribution.

Keywords : raw rubber material marketing, farmers share, organized marketing, tradisitional marketing 


\section{Pendahuluan}

Agribisnis karet saat ini sedang mengalami kondisi yang kurang menguntungkan karena menurunnya harga karet beberapa tahun terakhir. Harga karet mencapai puncak tertinggi pada tahun 2011, namun sejak tahun 2012 - 2018 harga karet cenderung mengalami penurunan hingga mencapai harga rata-rata USD 1,44 per kg (SICOM, 2017). Selama periode tersebut harga karet menyentuh ke level rata-rata USD 1,30/kg. Turunnya harga karet telah memberikan dampak yang signifikan terhadap kondisi sosial ekonomi petani di Sumatera Selatan (Syarifa et al., 2015). Menurut Hardiawan (2018); Regina (2016); Syarifa et al., (2015) dampak negatif turunnya harga karet bagi petani adalah : Banyak petani yang menghentikan kegiatan usaha tani karetnya dan beralih profesi, banyak lahan karet yang dikonversi ke komoditas lain, daya beli masyarakat menjadi lemah, tingkat kesejahteraan masyarakat menurun, banyak kredit kendaraan yang macet, kejahatan meningkat dan kualitas kesehatan dan pendidikan menjadi rendah.

Berbagai upaya dilakukan untuk menyikapi harga karet yang turun di tingkat petani di antaranya adalah: 1) Meningkatkan pendapatan petani dengan menanam klon berproduktivitas tinggi dan tanaman sela sebagai tambahan pendapatan (Hafsah et al., 2014; Mepriyanto et al., 2015; Septianita, 2009) serta 2) Meningkatkan kualitas bokar untuk meningkatkan efisiensi pemasaran melalui pemasaran terorganisir (Alamsyah et al., 2006; Alamsyah et al., 2017; Nancy et al., 2013; Wiyanto \& Kusnadi, 2013). Pemasaran bokar dengan menggunakan lelang ataupun kemitraan telah lama direkomendasikan untuk meningkatkan efesiensi pemasaran bokar di Sumatera Selatan. Namun kondisi tersebut tidak berjalan dengan baik sehingga pemasaran bokar melalui lelang dan kemitraan tidak berkembang pesat. Salah satu penyebabnya adalah karena pada saat itu harga karet di tingkat petani tidak memiliki perbedaan yang signifikan serta harga karet yang diterima oleh petani dengan menggunakan sistem pemasaran bokar secara tradisional masih mampu memenuhi kebutuhan keluarga sehingga pemasaran bokar terorganisir tidak menjadi pilihan petani untuk memasarkan bokar petani.

Pada saat ini, harga karet kembali mengalami penurunan berkepanjangan diiringi oleh kenaikan harga untuk kebutuhan keluarga sehingga harga karet yang diterima petani tidak lagi mampu menutupi kebutuhan keluarga, sedangkan petani tidak dapat mempengaruhi harga karet. Salah satu caranya adalah petani meningkatkan bagian harga yang diterima oleh petani adalah melalui pemasaran terorganisir sehingga yang memungkinkan posisi tawar petani karet akan meningkat. Oleh karena itu, penelitian ini dilakukan dengan bertujuan untuk memberikan gambaran bahwa dengan melakukan pemasaran bokar secara terorganisir dapat meningkatkan bagian harga yang diterima petani jika dibandingkan dengan pemasaran bokar secara tradisional serta memberikan gambaran manfaat lainnya yang diterima oleh petani yang telah melakukan pemasaran bokar terorganisir.

\section{Metode dan Bahan}

Kegiatan penelitian dilakukan pada tahun 2017 di 4 kabupaten di Sumatera Selatan, dari 4 kabupaten tersebut dipilih 6 sampel kelompok pemasaran bokar terorganisir dan 5 kelompok pemasaran bokar tradisional. Penelitian ini menggunakan 6 sampel pemasaran bokar yang terorganisir yang telah melaksanakan pemasaran bokar secara lelang dan 5 sampel kelompok pemasaran yang belum menggunakan sistem lelang atau kemitraan (masih menjual ke pedagang perantara). Pemilihan kelompok pemasaran bokar berdasarkan purposive sampling dengan pertimbangan kelompok yang sudah lama berdiri dan masih berjalan sampai saat ini dan memiliki pembukuan yang sudah tersusun rapi sehingga memudahkan untuk melihat data produksi dan harga yang diterima oleh kelompok pemasaran tersebut. Sedangkan pemasaran yang lainnya belum rapi dalam 
penyimpanan data produksi dan harganya. Hal tersebut juga yang mendasari adanya perbedaan jumlah sampel kelompok pemasarannya. Pengumpulan data dilakukan dengan metode survei dan literatur. Data yang dikumpulkan meliputi data primer dan data sekunder.

Data primer diperoleh melalui wawancara yang dilakukan langsung dengan pengurus kelompok/UPPB/Koperasi menggunakan daftar pertanyaan (questioner) yang telah dipersiapkan sebelumnya. Secara garis besar pertanyaan berisi tentang jumlah produksi, sistem pemasaran bokar, jumlah pedagang, harga yang ditawar pedagang, dan lain sebagainya. Selain itu, dilakukan pula wawancara terhadap petani yang masih memasarkan karetnya secara tradisional. Data sekunder diperoleh melalui studi pustaka dari Dinas Perkebunan, Gapkindo Sumatera Selatan, dan publikasi terkait dengan penelitian ini. Pengolahan data dilakukan secara kualitatif. Analisis kualitatif digunakan untuk memaparkan manfaat yang diterima oleh petani karet dalam mengikut kegiatan pemasaran terorganisir dan melihat bagian harga yang diterima oleh petani karet menggunakan pemasaran terorganisir maupun pemasaran bokar secara tradisional. Untuk melihat harga karet yang diterima petani dapat dilihat tahapan berikut:

1. Harga FOB SIR $20=$ (Harga SIR 20 di pelabuhan ekspor setempat $\mathrm{x}$ nilai tukar rupiah)

2. Harga bokar $100 \% \mathrm{KKK}=$ Harga FOB SIR 20 - (biaya pengolahan SIR $20+$ keuntungan pabrik SIR 20)

3. Harga beli atau jual bokar tingkat pabrik = (KKK bokar x harga bokar 100\% KKK)

4. Harga bokar petani $=$ Harga jual di tingkat pabrik - (biaya + keuntungan pedagang)

Komoditas karet merupakan produk ekspor sehingga untuk mementukan harga karet berdasarkan harga karet dunia. Tahapan diatas merupakan proses perhitungan harga yang akan diterima oleh petani karet mulai dari harga dunia kemudian sampai ke tingkat petani. Perhitungan harga karet menggunakan kadar karet kering sehingga yang terkandung didalam karet tidak lagi bercampur dengan air melainkan sudah $100 \%$ karet. Harga FOB SIR 20 merupakan harga karet di pelabuhan asal produk yang telah dikonversi kedalam kurs rupiah (sudah termasuk ongkos bongkar muat kapal), kemudian untuk menghitung harga karet ditingkat pabrik maka harga FOB SIR 20 tersebut akan dikurangi oleh biaya olah pabrik dan keuntungan pabrik yang ditetapkan pabrik (harga tersebut merupakan harga dipintu pabrik). Selanjutnya harga tersebut menjadi dasar perhitungan harga karet yang melakukan pemasaran terorganisir karena sudah menggunakan sistem lelang atau kemitraan (menggunakan supplier pabrik). Sedangkan untuk harga yang menggunakan pemasaran tradisional harus yaitu harga yang pabrik dikurangi biaya angkut dan keuntungan pedagang perantara.

Menurut Hamid (1972) untuk menentukan bagian harga yang diterima oleh petani dapat dirumuskan sebagai berikut :

$$
F s=\frac{P f}{P r} \times 100 \%
$$

Dimana:

Fs $=$ Farmers Share $($ Bagian Harga $)(\%)$

Pf = Harga karet ditingkat petani $(\mathrm{Rp} / \mathrm{kg})$

$\operatorname{Pr}=$ Harga karet ditingkat pabrik/pedagang $(\mathrm{Rp} / \mathrm{kg})$

\section{Hasil dan Pembahasan}

\section{Pemasaran Bahan Olah Karet (Bokar) di Sumatera Selatan}

Pemasaran bokar merupakan kegiatan akhir dari seluruh rangkaian kegiatan budidaya karet. Tanaman karet yang memasuki waktu panen akan dilakukan pemanenan dengan cara menyadap batang karet sehingga menghasilkan getah karet. Getah karet tersebut diolah menjadi bokar kemudian akan dipasarkan kepada pembeli bokar. Pemasaran bokar karet terdiri dari dua pemasaran yaitu pemasaran bahan olah karet 
(bokar) secara terorganisir dan tradisional. Pemasaran bokar yang dilakukan petani pada umumnya masih menggunakan pemasaran bokar secara tradisional, karena pada umumnya penguasaan kebun karet rakyat menguasai $85 \%$ dari luasan kebun karet yang ada di Indonesia (Agustina et al., 2013; Herdiansyah, 2015). Beberapa alasan petani masih menggunakan pemasaran tradisional antara lain:

1. Keberadaan kebun karet rakyat tersebar dan jarak kebun petani ke pabrik karet tergolong jauh, dengan begitu petani terkadang enggan untuk mengumpulkan bokarnya di suatu titik pengumpulan tertentu untuk berjualan bokar serta jauhnya lokasi pabrik tidak dibarengi dengan fasilitas sarana jalan dan transportasi yang memadai sehingga jika petani angkut juga akan naik.

2. Petani masih menjual bokar berdasarkan atas berat basah, sehingga petani tidak mengutamakan kualitas dari bokar yang dihasilkan. Terkadang petani mencampur bokar dengan kontaminan yang lainnya seperti tanah, pasir, tatal dan kontaminan yang lainnya.

3. Tidak terikat oleh peraturan yang berlaku serta dapat meminjam uang kepada pedagang perantara untuk keperluan rumah tangga sehingga petani secara tidak langsung sudah terikat oleh pedagang perantara untuk selalu menjual bokar kepada pedagang perantara.

Peningkatkan mutu bokar memerlukan peran seluruh pihak baik petani, pedagang, pabrik maupun pemerintah. Kegiatan yang dilakukan oleh pemerintah untuk meningkatkan posisi tawar melalui Peraturan Menteri Pertanian No. 38/Permentan/OT.140 /8/2008 tentang Pedoman Pengolahan dan Pemasaran Bahan Olah Karet dalam rangka implementasi Standar Nasional Indonesia (SNI) tersebut (Kementerian Pertanian, 2008). Hal ini sejalan dengan implementasi SNI tersebut oleh Kementerian Perdagangan yang dituangkan dalam peraturan Menteri Perdagangan No. 53/M-DAG/PER/10/2009 tentang Pengawasan Mutu Bahan Olah
Komoditi Ekspor Standard Indonesian Rubber (Kementerian Perdagangan, 2009). Bentuk pemasaran bokar terorganisir dengan sistem lelang atau kemitraan melalui Unit Pengolahan dan Pemasaran Bokar (UPPB). Pemasaran bokar melalui UPPB ini sudah dikembangkan sejak lama dan setiap tahunnya jumlahnya terus mengalami peningkatan untuk mengakomodir seluruh bokar dari penghasil karet di Sumatera Selatan.

UPPB merupakan suatu unit usaha yang dibentuk oleh dua atau lebih kelompok pekebun untuk melakukan kegiatan bimbingan teknis, pengolahan dan pemasaran bokar (Direktorat Jenderal Pengolahan dan Pemasaran Hasil Pertanian, 2011). UPPB memiliki legalitas dengan adanya STR-UPPB yaitu surat tanda registrasi yang terdaftar di pemerintahan kabupaten/kota. Tanda registrasi tersebut merupakan salah satu syarat untuk bokar dapat diterima oleh pabrik dan bokar akan dapat diidentifikasi asal usul bokar tersebut. Oleh karena itu, pemasaran bokar melalui UPPB sangat didukung penuh oleh pemerintah kabupaten kota sehingga dengan adanya dukungan tersebut, UPPB memiliki posisi yang cukup kuat untuk memotong saluran tata niaga bokar menjadi lebih efisien dan mendapatkan bagian harga bokar yang lebih tinggi (Syaputra, 2018). Perkembangan jumlah UPPB di Sumatera Selatan dapat dilihat pada Tabel 1.

Berdasarkan Tabel 1 dapat dilihat bahwa jumlah UPPB di Sumatera Selatan baru berjumlah 177 yang telah menggunakan sistem lelang atau kemitraan langsung dengan pabrik karet. Jumlah tersebut masih terbilang cukup kecil karena pada umumnya jumlah UPPB setiap desa penghasilkan karet terdapat satu kelompok UPPB. Dengan adanya satu UPPB di masing - masing desa akan mengurangi rantai pemasaran bokar di desa penghasil karet. Desa penghasil karet yang ada di Sumatera Selatan berjumlah 2.500 desa. Sehingga untuk mengoptimalkan pemasaran bokar yang lebih efisien, karena dengan menggunakan rantai pemasaran yang efisien akan meningkatkan bagian harga yang diterima oleh petani (Syarifa et al., 2016).

Sebaran jumlah UPPB di Sumatera Selatan 
Tabel 1. Jumlah UPPB di Sumatera Selatan, 2013-2018

\begin{tabular}{|c|c|c|c|c|c|}
\hline \multirow{2}{*}{ Kabupaten } & \multirow{2}{*}{$\begin{array}{l}\text { Jumlah } \\
\text { UPPB }\end{array}$} & \multirow{2}{*}{ Tahun Registrasi } & \multicolumn{2}{|c|}{ Volume per tahun (ton) } & \multirow{2}{*}{ Total } \\
\hline & & & Kemitraan & Lelang & \\
\hline Ogan Ilir & 16 & 2014 (12), 2015 (1), 2018 (3) & - & 6.444 & 6.444 \\
\hline Muara Enim & 28 & $2013(28)$ & 14.040 & 5.664 & 19.704 \\
\hline Banyuasin & 52 & $\begin{array}{l}2014 \text { (32), } 2016 \text { (11), } 2017 \text { (7), } \\
2018 \text { (2) }\end{array}$ & - & 14.183 & 14.183 \\
\hline OKU Induk & 12 & $2018(12)$ & - & 5.556 & 5.556 \\
\hline OKU Timur & 2 & $2004(2)$ & & 360 & 360 \\
\hline Prabumulih & 2 & $2014(2)$ & - & 3.840 & 3.840 \\
\hline OKI & 5 & $2014(4), 2015(1)$ & - & 899 & 899 \\
\hline Lahat & 2 & $2014(1), 2018(1)$ & - & 432 & 432 \\
\hline Musi Rawas & 10 & $2015(10)$ & 713 & - & 713 \\
\hline Lbk Linggau & 4 & $2014(4)$ & - & - & - \\
\hline $\begin{array}{l}\text { Musi } \\
\text { Banyuasin }\end{array}$ & 43 & $\begin{array}{l}2015 \text { (1), } 2016 \text { (17), } 2017 \text { (18), } \\
2018 \text { (7) }\end{array}$ & - & 8.666 & 8.666 \\
\hline PALI & 1 & 2015 (1) & - & 3.360 & 3.360 \\
\hline Total & 177 & & 14,753 & 35.221 & 49.974 \\
\hline
\end{tabular}

Sumber : Dinas Perkebunan Sumatera Selatan dan Data diolah, 2018

jumlah yang paling banyak adalah dari Kabupaten Banyuasin terbentuk 52 UPPB, Musi Banyuasin terbentuk 43 UPPB, Kabupaten Muara Enim terbentuk 28 UPPB, Ogan Ilir terdapat 16 UPPB, sedangkan Kabupaten lainnya tergolong rendah. Waktu penjualan bokar petani tidak terlalu beragam, yaitu mingguan, dua mingguan dan bulanan dengan tanggal yang telah ditentukan sesuai dengan kesepakatan anggota UPPB. Untuk kontribusi UPPB terhadap produksi karet Sumatera Selatan masih sangat rendah, yaitu masih mencapai $6 \%$ dari total produksi karet (Junaidi, 2017). Oleh karena itu, diperlukan upaya untuk menarik petani agar bergabung dalam pemasaran teroganisir dan melalui UPPB untuk mewujudkan kualitas bokar bersih serta perlunya UPPB didukung oleh semua lembaga sehingga mutu karet nasional membaik dan harga yang diterima oleh petani akan meningkat. Hal tersebut perlu dukungan dari semua lembaga terkait.

\section{Bagian Harga yang Diterima Petani}

Farmer's Share atau bagian harga yang diterima petani merupakan persentase perbandingan harga yang ada di tingkat petani karet dengan harga yang ada di pabrik pengolahan karet sebagai konsumen tingkat akhir. Hasil bagian harga yang diterima petani, baik kecil maupun besar menunjukkan merata atau tidaknya pembagian hasil oleh pedagang pengumpul dan pedagang besar terhadap petani karet. Bagian harga yang diterima petani karet akan semakin kecil jika terlalu banyak pihak yang terlibat dalam pemasaran bokar. Semakin kecil bagian harga yang 
diterima petani, menunjukkan bahwa petani karet hanya berperan sebagai penerima harga. Sehingga semakin pendek rantai pemasaran bokar, maka bagian harga yang diterima oleh petani juga akan semakin besar. Rantai pemasaran bokar melalui UPPB tergolong pendek yaitu dari kelompok tani (UPPB) akan di tawar langsung oleh pedagang besar kemudian langsung ke pabrik karet, namun ada juga dari UPPB langsung ditawar oleh pabrik. Kedua rantai pemasaran tersebut sangat efisien karena tidak banyak pedagang yang mengambil keuntungan dalam kegiatan pemasaran bokar tersebut (Antoni \& Purbiyanti, 2015). Bagian harga yang diterima oleh petani dari masing-masing pemasaran dapat dilihat pada Tabel 2.

Berdasarkan Tabel 2 dapat dilihat bahwa bagian harga yang diterima dari pemasaran bokar melalui UPPB berkisar 75\%-89\% lebih tinggi dibandingkan pemasaran bokar tradisional dengan mencapai 50\%-58\%.
Besaran bagian harga yang diterima melalui UPPB telah sesuai dengan Peraturan Menteri Pertanian No. 38/Permentan/OT. 140 /8/2008 tentang Pedoman Pengolahan dan Pemasaran Bahan Olah Karet tentang bagian harga yang diterima petani adalah $75 \% \mathrm{FOB}$, sedangkan variasi bagian harga yang diterima oleh kelompok pemasaran bokar yang disebabkan karena adanya perbedaan jarak ke pabrik sehingga ada biaya transport yang dapat mengurangi bagian harga bokar petani, selain itu juga disebabkan oleh waktu pelaksanaan lelang atau kemitraan karena setiap hari harga karet berfluktuasi berdasarkan harga internasional. Sehingga dengan demikian, bagian harga tersebut sudah tergolong rantai pemasaran yang efisien (Rahman, 2015), serta dapat meningkatkan posisi tawar petani semakin kuat (Febriyanto, 2017). Rantai pemasaran yang efisien dapat dilihat pada Gambar 1.

Tabel 2. Bagian harga yang diterima petani dan pada pemasaran terorganisir dan pemasaran tradisional

\begin{tabular}{lcc}
\hline \multicolumn{1}{c}{ Diskripsi } & $\begin{array}{c}\text { Bagian Harga Petani } \\
(\% \text { FOB SIR 20 })\end{array}$ & Waktu lelang \\
\hline Pemasaran Terorganisir: & 78 & Mingguan \\
- UPPB Lavender & 75 & Mingguan \\
- UPPB Cipta Praja & 81 & Mingguan \\
- UPPB Maju Bersama & 89 & Mingguan \\
- KUD Berkat & 76 & Dua mingguan \\
- KUD Mupakat Jaya & 82 & Dua mingguan \\
- KUD Serasan Jaya & $50-58$ & Mingguan \\
\hline
\end{tabular}

Sumber: Primer, 2017

Keterangan :

KKK pemasaran bokar terorganisir : $52 \%$ - 58\% (Mingguan)

KKK pemasaran bokar tradisional : 45\% - 47\% (Mingguan) 


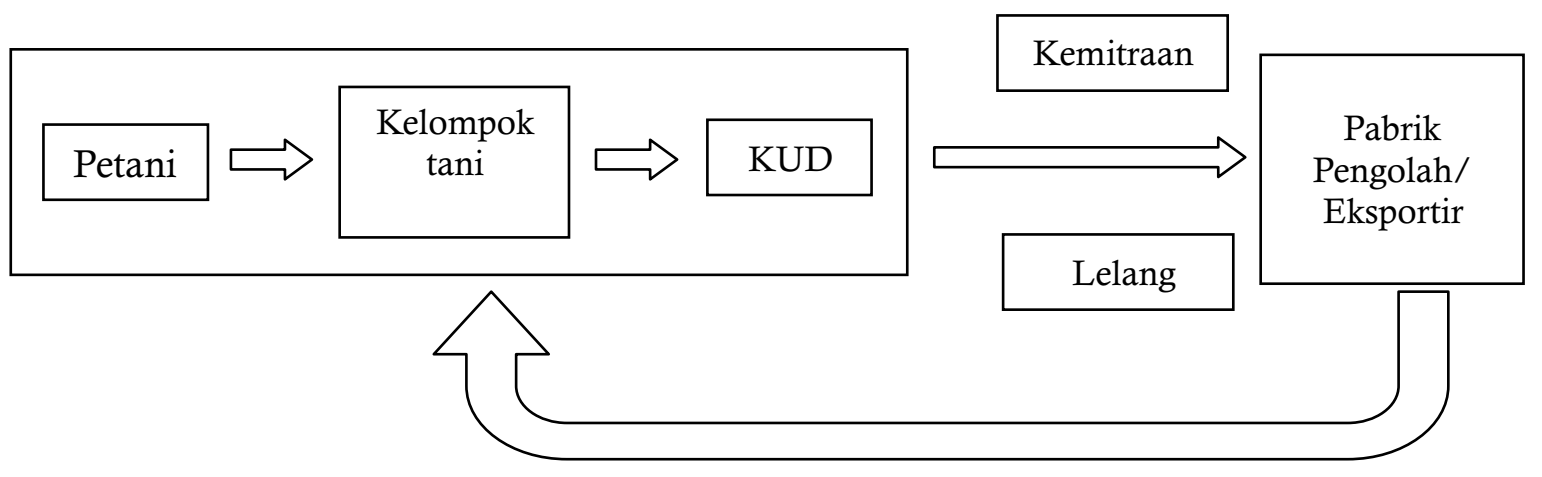

Gambar 1. Rantai pemasaran bokar terorganisir

Gambar 1 menunjukkan bahwa rantai pemasaran terorganisir sangat pendek yaitu kumpulan beberapa petani yang membentuk menjadi kelompok tani, kelompok tani tersebut membentuk badan hukum seperti Koperasi Unit Desa (KUD), Koperasi, maupun UPPB melakukan pemasaran bokar langsung ke pabrik melalui kegiatan kemitraan atau lelang (supplier pabrik menawar bokar petani) ataupun pabrik membeli bokar langsung ke UPPB. Sistem ini merupakan pemasaran yang sangat efisien karena tidak banyak tataniaga yang terlibat sehingga bagian harga yang diterima oleh petani menjadi besar. Selain meningkatkan harga bokar petani, UPPB juga memberikan keuntungan kepada pabrik karena pihak pabrik tidak perlu lagi melakukan pencucian karet dengan proses panjang sehingga biaya produksi pengolahan menjadilebih murah (Junaidi, 2018).

Bagian harga yang diterima oleh petani yang melakukan pemasaran tradisional tergolong rendah dikarenakan panjangnya rantai pemasaran bokar. Rantai pemasaran bokar yang panjang akan mengurangi bagian harga petani karena setiap rantai tata niaga mengambil marjin keuntungan dan biaya pemasaran yang akan dibebankan harga yang diterima oleh petani. Untuk melihat rantai pemasaran bokar secara tradisional dapat dilihat pada Gambar 2.

Gambar 2 menunjukkan bahwa rantai pemasaran bokar secara tradisional tergolong panjang. Berikut beberapa alternatif rantai pemasaran bokar secara tradisional:

1 . petani $\longrightarrow$ pedagang desa $\longrightarrow$ pedagang besar $\longrightarrow$ pool pabrik $\rightarrow$ pabrik pengolahan dan eksportir

2. petani $\longrightarrow$ pedagang desa $\longrightarrow$ pool pabrik $\rightarrow$ pabrik pengolahan dan eksportir

3. petani $\longrightarrow$ pedagang besar $\rightarrow$ pool pabrik $\rightarrow$ pabrik pengolahan dan eksportir

4. petani $\longrightarrow$ pool pabrik $\longrightarrow$ pabrik pengolahan dan eksportir

Dari keempat saluran pemasaran bokar tersebut terdapat saluran pemasaran pertama adalah salah pemasaran terpanjang sehingga setiap tata niaga pemasaran akan mengambil keuntungan dan biaya pemasaran yang akan mengurangi bagian harga yang diterima oleh

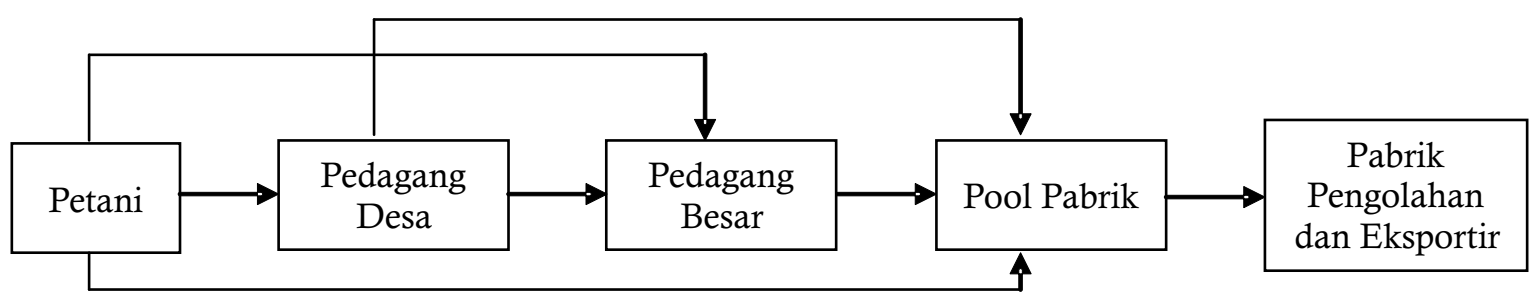

Gambar 2. Rantai pemasaran bokar secara tradisional 
petani. Sedangkan saluran pemasaran 4 adalah saluran pemasaran bokar terpendek, namun, ada beberapa faktor yang menjadikan harga yang diterima oleh petani tersebut rendah salah satunya adalah mutu bokar yang dihasilkan petani tradisional sangat beragam, volume yang dihasilkan oleh petani sangat sedikit, lokasi petani yang tersebar sehingga membutuhkan biaya transportasi yang lebih untuk mengambil bokar petani, serta adanya sangkutan utang piutang petani kepada pedagang perantara menjadikan posisi tawar petani menjadi lemah. Faktor tersebut menjadikan bagian yang diterima oleh petani menjadi rendah. Perbedaan sistem pemasaran bokar juga akan mempengaruhi sistem pengolahan bokar ditingkat petani untuk melihat kondisi pengolahan bokar melalui pemasaran terorganisir maupun tradisional dapat dilihat pada Tabel 3.

Tabel 3. Pengolahan bokar yang dihasilkan melalui pola pemasaran bokar secara terorganisir dan pemasaran bokar secara tradisional

\begin{tabular}{clcc}
\hline Uraian & Tradisional (\%) & $\begin{array}{c}\text { Lelang/Kemitraan (\%) } \\
\text { (7desa) }\end{array}$ & $\begin{array}{c}\text { (7 Kelompok Pemasaran } \\
\text { Bokar Terorganisir) }\end{array}$ \\
\hline Jenis Pembeku & Asam semut/ Deorub & 0 & 82 \\
& Cuka para & 98 & 18 \\
& Pupuk & 1 & 0 \\
Tempat Pembekuan & Tawas & 1 & 0 \\
& Kotak kayu & 70 & 0 \\
& Plastik & 25 & 100 \\
Penyimpanan Bokar & Lubang tanah & 5 & 0 \\
& Direndam & 60 & 100 \\
\hline
\end{tabular}

Sumber: Primer, 2017

Tabel 3. menunjukkan bahwa adanya perbedaan dari sistem pengolahan bokar yang dilakukan oleh petani karet dari masing masing sistem pemasaran. Dapat dilihat bahwa penggunaan jenis pembeku untuk pengumpalan karet pada umumnya di pemasaran terorganisir sudah menggunakan pembeku anjuran, hanya $18 \%$ petani yang masih menggunakan cuka para, hal tersebut karena kelompok tersebut baru mulai berkelompok dan kesulitan untuk mendapatkan bahan pembeku anjuran. Sedangkan di petani tradisional pada umumnya masih menggunakan pembeku yang tidak sesuai anjuran yaitu dengan menggunakan cuka para sebesar 98\%, penggunaan bahan ini tidak baik dilakukan karena akan merusak mutu karet (Handayani, 2014).
Sedangkan penggunaan tempat pembeku untuk pemasaran terorganisir, seluruhnya sudah menggunakan kotak plastik sedangkan yang tradisional masih ada yang menggunakan lubang tanah. Serta sistem penyimpanan bokar petani yang terorganisir sudah tidak lagi direndam karena petani menyadari bahwa petani tidak menjual bobot basah melainkan karet kering. Sedangkan petani yang masih bersifat tradisional masih melakukan perendaman dengan harapan bokarnya lebih berat. Hal ini sejalan dengan penelitian yang dilakukan oleh Syarifa et al. (2013) dan Vachlepi et al. (2016) yang menyatakan bahwa petani yang melakukan penjualan secara tradisional cenderung menyimpan bokarnya dengan cara direndam di sungai atau kolam agar bobot bokar lebih berat. Kondisi penyimpanan bokar sebelum dijual dapat dilihat pada Gambar 3. 

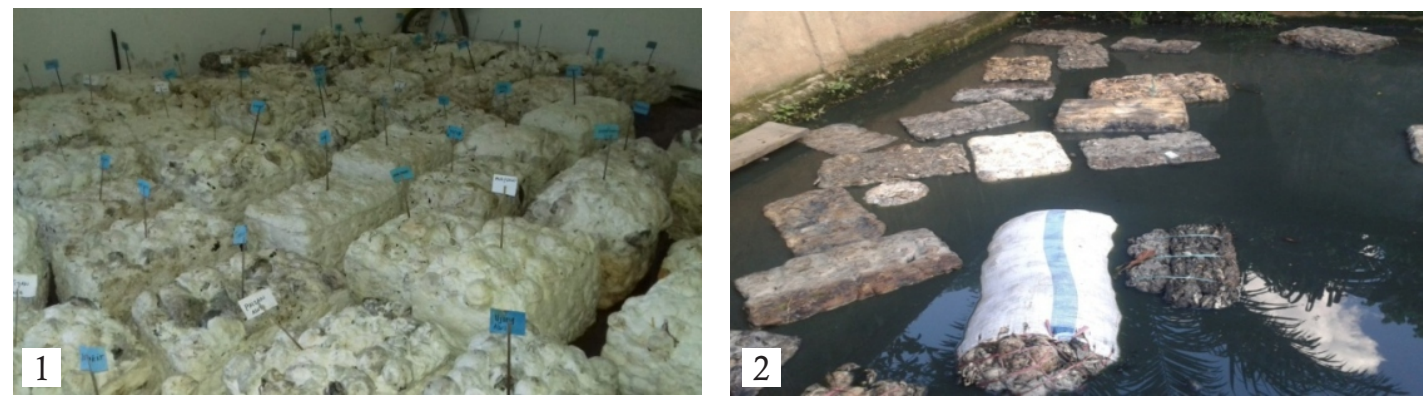

Gambar 3. Kondisi penyimpanan bokar petani yang menggunakan sistem pemasaran terorganisir (1) dan penyimpanan bokar secara tradisional (2)

Gambar 3 menunjukkan adanya perbedaan penyimpanan bokar sebelum dijual kepada pembeli. Kondisi sistem pemasaran terorganisir memperlihatkan bokar yang tidak terendam dengan air, proses penyimpanan bokar yang melalukan pemasaran terorganisir yaitu bekuan lateks yang telah dibiarkan selama 4-5 hari di kebun lalu dikumpulkan ke sebuah wadah, selanjutnya bekuan lateks dijadikan satu dengan memberikan lateks segar kedalam wadah tersebut sehingga diberikan pembeku anjuran, kemudian didiamkan maksimal satu malam selanjutkan bokar di keluarkan dari wadah cetakan dan disimpan diruangan yang teduh. Sedangkan penyimpanan untuk pemasaran tradisional setelah dicetak di dalam wadah kemudian bokar dikeluarkan dan dimasukkan kedalam kolam atau sumur, jika petani ingin menjual baru bokar tersebut dikeluarkan dari kolam.

\section{Manfaat Pemasaran Bokar Terorganisir}

Pemasaran bokar secara terorganisir merupakan salah satu upaya yang dilakukan oleh pemerintah untuk meningkatkan penerimaan petani melalui peningkatan bagian harga yang diterima petani menjadi lebih tinggi (Nugraha et al., 2018). Ada beberapa manfaat dengan adanya penerapan pemasaran bokar terorganisir yaitu, mutu bokar lebih baik, posisi tawar petani meningkat, harga lelang menjadi patokan bagi pedagang perantara, dan petani yang sudah berkelompok akan memudahkan pemerintah dalam melakukan pembinaan mutu bokar maupun penyaluran bantuan petani karet.

1. Mutu bokar lebih baik.

Pemasaran bokar terorganisir merupakan pemasaran bokar yang memiliki aturan dan payung hukum sehingga pengembangan pemasaran bokar terorganisir dapat mempengaruhi mutu bokar nasional. Persyaratan yang telah ditetapkan oleh pemasaran bokar terorganisir mewajibkan harus bersih dari tatal, pengolahannya tidak boleh direndam, tidak mengandung kontaminan dan tidak terkena sinar matahari langsung, menggunakan pembeku anjuran (Hutapea, 2018; Kementerian Pertanian, 2018; Nancy et al., 2012).

2. Posisi tawar petani meningkat.

Posisi tawar petani karet pada awalnya sangat lemah dikarenakan petani menjual bokar secara tradisional atau mandiri kepada pedagang perantara tingkat desa. Untuk meningkatkan posisi tawar petani dengan kolektifikasi dalam pemasaran produk pertanian. Hal ini dilakukan untuk mencapai efisiensi biaya pemasaran bokar dengan skala kuantitas yang lebih besar, dan menaikkan posisi tawar petani karet.

3. Harga lelang menjadi patokan bagi pedagang perantara.

Kolektifikasi pemasaran bokar dilakukan untuk mengkikis jaring-jaring tengkulak dalam menekan posisi tawar petani dalam penentuan 
harga secara individual. Upaya kolektifikasi tersebut tidak berarti menghapus peran dan posisi pedagang distributor dalam rantai pemasaran, namun tujuan utamanya adalah merubah pola relasi yang merugikan petani produsen dan membuat pola distribusi lebih efisien dengan pemangkasan rantai tata niaga yang tidak menguntungkan. Posisi tawar petani yang tinggi akan berdampak kepada bagian harga yang diterima petani akan meningkat sehingga dapat meningkatkan pendapatan petani karet. Selain itu juga harga ditingkat petani akan terdongkrak karena pedagang perantara menyesuaikan harga pemasaran bokar terorganisir sehingga bokar petani tidak seluruhnya masuk kedalam pemasaran bokar terorganisir. Adanya kebijakan tersebut, maka harga eceran bokar di pedagang perantara akan meningkat.

4. Memudahkan pemerintah dalam melakukan pembinaan mutu bokar maupun penyaluran bantuan petani karet.

Untuk menjaga dan meningkatkan mutu bokar, maka pada pemasaran bokar melalui UPPB ini, baik pada pola lelang maupun kemitraan, pemerintah kabupaten/kota atau instansi yang ditunjuk, melakukan pembinaan kepada pekebun secara terjadwal. Pembinaan tersebut berupa penyuluhan, pelatihan, evaluasi, pendampingan, pemberian bantuan fasilitas peralatan, bahan pembeku, pemberian Surat Tanda Registrasi. Surat tersebut sebagai bentuk legalitas terdaftar dari pemerintahan kabupaten/kota yang menunjukkan bahwa kegiatan pengolahan dan pemasaran bokar mendapat bimbingan dan pembinaan dari pemerintah. Pada UPPB pola kemitraan ada penekanan pada jaminan ketersediaan bahan baku pabrik pengolahan sesuai baku mutu, terbentuknya harga pasar yang wajar dan terwujudnya peningkatan nilai tambah bagi pekebun. Pihak mitra terhadap pekebun diharapkan juga menyediakan bahan penggumpal dan atau pengawet, sarana produksi, pemasaran bokar, transportasi/ pengangkutan dan memberikan fasilitasi permodalan pada pekebun.

\section{Kesimpulan}

Berdasarkan pembahasan dapat disimpulkan bahwa untuk meningkatkan pendapatan petani salah satunya dengan melakukan pemasaran bokar terorganisir, karena dengan pemasaran bokar terorganisir akan meningkatkan bagian harga yang diterima oleh petani karet. Rata-rata bagian harga yang diterima petani adalah $80 \%$ FOB untuk pemasaran bokar terorganisir dan 50\% $58 \%$ FOB untuk pemasaran bokar tradisional. Selain itu juga dengan sistem pemasaran bokar terorganisir, terutama dengan sistem lelang memberikan manfaat bagi petani antara lain mutu bokar lebih baik, posisi tawar petani meningkat, harga lelang menjadi acuan bagi petani di sekitarnya, bagian harga yang diterima petani meningkat dan adanya pembinaan dan bantuan dari pemerintah melalui dinas perkebunan di kabupaten produksi karet. Rantai pemasaran secara terorganisir lebih efisien dibandingkan dengan pemasaran tradisional. Hal tersebut dikarenakan pemasaran terorganisir tidak lagi menggunakan pedagang yang akan mengambil marjin keuntungan sehingga dapat mengurangi bagian harga petani melainkan langsung ke pool pabrik. Sedangkan pemasaran secara tradisional masih menggunakan pedagang perantara dan kuantitas barang tidak sebanyak pemasaran secara terorganisir sehingga bagian harga yang terima petani juga lebih rendah dibandingkan pemasaran secara terorganisir.

\section{Daftar Pustaka}

Agustina, D. S., Syarifa, L. F., \& Nancy, C. (2013). Kajian kelembagaan dan kemitraan pemasaran kayu karet di provinsi sumatera selatan. Jurnal Penelitian Karet, 31(1), 54-67.

Alamsyah, Z., Napitupulu, D., Elwamendri, \& Suprayitno. (2006). Laporan Penelitian: Analisis pemasaran bokar suatu kajian terhadap upaya peningkatan kesejahteraan petani melalui pembenahan tata niaga bokar di Provinsi Jambi. Diakses dari Fakultas Pertanian Universitas Jambi. 
Alamsyah, A., Nugraha, I. S., Agustina, D. S., \& Vachlepi, A. (2017). Tinjauan penerapan unit pengolahan dan pemasaran bokar untuk mendukung gerakan nasional bokar bersih di sumatera selatan. Warta Perkaretan, 36(2), 159-172.

Antoni, M., \& Purbiyanti, E. (2015). Laporan Penelitian: Pola pemasaran dan bentuk pasar karet rakyat dan dampaknya bagi kesejahteraan petani karet rakyat di Sumatera Selatan. Diakses dari Lembaga Penelitian Universitas Sriwijaya, Indralaya.

Direktorat Jenderal Pengolahan dan Pemasaran Hasil Pertanian. (2011). Pedoman Penerapatan Jaminan Sistem Mutu Bokar. Jakarta, Indonesia: Direktorat Jenderal Pengolahan dan Pemasaran Hasil Petanian.

Febriyanto. (2017). Optimalisasi pemasaran melalui pembentukan kelompok hasil panen budi daya karet Rajabasa Lama Labuhan Ratu Lampung Timur. Sinar Sang Surya, 1(1), 35-41.

Hafsah, F. M., Violeta, P. C., Pratama, C., \& Novindra. (2014). Laporan Penelitian: Analisis Pendapatan dan Tingkat Kesejahteraan Petani Karet Perkebunan Plasma Desa Sungai Hijau Kecamatan Pangkalan Banteng Kabupaten Kota Waringin Barat Kalimantan Tengah. Diakses dari Institut Pertanian Bogor.

Hamid, A. K. (1972). Tataniaga pertanian. Makasar, Indonesia: Universitas Hasanudin

Handayani, H. (2014). Pengaruh berbagai jenis penggumpal padat terhadap koagulum dan vulkanisat karet alam. Jurnal Penelitian Karet, 32(1), 74-80.

Hardiawan, D. (2018). Harga karet rendah, begini dampak secara tidak langsung ke investasi. $\mathrm{D} \mathrm{i}$ a $\mathrm{k} \mathrm{s}$ e $\mathrm{s}$ $\mathrm{d}$ a $\mathrm{r}$ i http://jambi.tribunnews.com/2018/05/1 $6 /$ harga-karet-rendah-begini-dampaksecara-tidak-langsung-ke-investasi.

Herdiansyah, R. (2015). Sistem pemasaran karet rakyat di kabupaten tebo provinsi jambi dengan pendekatan rantai pasok. (Tesis), Institut Pertanian Bogor, Bogor.
Hutapea, Y. (2018). Manfaat pemasaran bahan olah karet terorganisir. Diakses dari http://sumsel.litbang.pertanian.go.id/BP TPSUMSEL/berita-manfaat-pemasaranbahan-olah-karet-terorganisir.html.

Junaidi, D. (2017). Evaluasi pelaksaan bokar bersih. Banjarbaru, Indonesia: Kementerian Pertanian.

Junaidi, D. (2018). Uppb berhasil mengangkat harga karet petani. Diakses dari http://www.agrofarm.co.id/2018/12/109 $05 \%$.

Kementerian Perdagangan. (2009). Peraturan menteri perdagangan no $53 / \mathrm{m}$ dag/per/10/2009 tentang pengawasan mutu bahan olah komoditi ekspor indonesia rubber yang diperdagangkan. Jakarta, Indonesia: Kementerian Perdagangan.

Kementerian Pertanian. (2008). Peraturan menteri pertanian no $38 /$ permentan/ot.140/8/2008 tentang pengolahan dan pemasaran bahan olah karet. Jakarta, Indonesia: Kementerian Pertanian.

Mepriyanto, Firdaus, T., \& Huda, N. (2015). Analisis faktor-faktor yang mempengaruhi pendapatan petani karet di Kecamatan Singingi Kabupaten Kuantan Singingi Provinsi Riau. E-Journal Bung Hatta, 7(3), 115.

Nancy, C., Agustina, D. S., \& Syarifa, L. F. (2013). Potensi kayu hasil peremajaan karet rakyat untuk memasok industri kayu karet. Jurnal Penelitian Karet, 31(2), 68-78.

Nancy, C., Hendratno, S., Supriadi, M., \& Anwar, C. (2012). Pemasaran Bokar. In S. Ismawanto, J. Saputra, L. F. Syarifa, \& M. Purbaya (Eds.), Saptabina usahatani karet rakyat edisi khusus. Palembang: Balai Penelitian Sembawa.

Nugraha, I. S., Alamsyah, A., \& Sahuri. (2018). Effort to increase rubber farmer's income when rubber low prices. Jurnal Perspektif Pembiayaan Dan Pembangunan Daerah, 4(2), 185-197.

Rahman, H. (2015). Pengembangan pasar lelang forward komoditas bahan olah karet (bokar) di Provinsi Sumatera Selatan. Agri Ekonomika, 4(2), 185-197. 
Regina, Y. (2016). Dampak sosial pasca penurunan harga karet (studi di Desa Mangat Baru Kecamatan Dedai Kabupaten Sintang, Kalimantan Barat). Jurnal Sosiologi, 4(2), 1-17.

Septianita. (2009). Faktor-faktor yang mempengaruhi petani karet rakyat melakukan peremajaan karet di Kabupaten Ogan Komering Ulu. Jurnal Agronobis, 1(1), 130-136.

Syaputra, D. J. (2018). Pengaruh program unit pengolahan dan pemasaran bokar (uppb) terhadap keterampilan petani karet di Kecamatan Karang Bintang Kabupaten Tanah Bumbu Provinsi Kalimantan Selatan. (Skripsi), Universitas Pasundan. diakses dari http://repository.unpas.ac.id/39227/

Syarifa, L. F., Agustina, D. S., Alamsyah, A., \& Nugraha, I. S. (2016). Potensi dan kendala dalam penguatan dan penumbuhan kelompok pemasaran bahan olah karet terorganisir di Provinsi Sumatera Selatan. Jurnal Penelitian Karet, 34(2), 237-246.
Syarifa, L. F., Agustina, D. S., \& Nancy, C. (2013). Evaluasi pengolahan dan mutu bahan olah karet rakyat (bokar) di tingkat petani karet di Sumatera Selatan. Jurnal Penelitian Karet, 31(2), 139-148.

Syarifa, L. F., Agustina, D. S., Nancy, C., \& Supriadi, M. (2015, 2-6 November). Socioeconomic condition as affected by fall of natural rubber price: case study in South Sumatera. Tulisan disajikan pada International Rubber Conference 2015, Ho Chi Minh.

Vachlepi, A., Nugraha, I. S., \& Alamsyah, A. (2016). Mutu bokar dari kebun petani di areal operasional tambang Kabupaten Musi Banyuasin. Jurnal Standarisasi, 18(2), 83-90.

Wiyanto, \& Kusnadi, N. (2013). Faktor-faktor yang mempengaruhi kualitas karet perkebunan rakyat (kasus perkebunan rakyat di Kecamatan Tulang Bawang Tengah Kabupaten Tulang Bawang Lampung). Jurnal Agribisnis Indonesia, 1(1), 39-58. 